\title{
Diversity and Distribution of Heavy Metal-Resistant Bacteria in Polluted Sediments of the Araça Bay, São Sebastião (SP), and the Relationship Between Heavy Metals and Organic Matter Concentrations
}

\author{
Bruna Del Busso Zampieri ${ }^{1}$. Aline Bartelochi Pinto ${ }^{1} \cdot$ Leonardo Schultz $^{3}$. \\ Marcos Antonio de Oliveira ${ }^{3}$ - Ana Julia Fernandes Cardoso de Oliveira ${ }^{2}$
}

Received: 17 May 2016 / Accepted: 13 July 2016 /Published online: 1 August 2016

(C) Springer Science+Business Media New York 2016

\begin{abstract}
Heavy metals influence the population size, diversity, and metabolic activity of bacteria. In turn, bacteria can develop heavy metal resistance mechanisms, and this can be used in bioremediation of contaminated areas. The purpose of the present study was to understand how heavy metals concentration influence on diversity and distribution of heavy metal-resistant bacteria in Araça Bay, São Sebastião, on the São Paulo coast of Brazil. The hypothesis is that activities that contribute for heavy metal disposal and the increase of metals concentrations in environment can influence in density, diversity, and distribution of heavy metal-resistant bacteria. Only $12 \%$ of the isolated bacteria were sensitive to all of the metals tested. We observed that the highest percentage of resistant strains were in areas closest to the São Sebastião channel, where port activity occurs and have bigger heavy metals concentrations. Bacterial isolated were most resistant to $\mathrm{Cr}$, followed by $\mathrm{Zn}, \mathrm{Cd}$, and $\mathrm{Cu}$. Few strains resisted to $\mathrm{Cd}$ levels greater than $200 \mathrm{mg} \mathrm{L}^{-1}$. In respect to $\mathrm{Cr}, 36 \%$ of the strains were able to grow in the presence of as much as $3200 \mathrm{mg} \mathrm{L}^{-1}$. Few strains were able to grow at concentrations of $\mathrm{Zn}$ and $\mathrm{Cu}$ as high as $1600 \mathrm{mg} \mathrm{L}^{-1}$, and none grew at the highest concentration of $3200 \mathrm{mg} \mathrm{L}^{-1}$. Bacillus sp. was most frequently
\end{abstract}

Bruna Del Busso Zampieri

brunadbzampieri@gmail.com

1 Biochemistry and Microbiology Department, Biology Institute, São Paulo State University—Rio Claro Campus (UNESP Rio Claro), São Paulo, Brazil

2 Marine Microbiology Laboratory (MICROMAR), Biosciences Institute, São Paulo State University-UNESP, Coastal Campus, São Paulo, Brazil

3 Molecular Structural Biology Laboratory, Biosciences Institute, São Paulo State University_UNESP, Coastal Campus, São Paulo, Brazil isolated and may be the dominant genus in heavy metalpolluted areas. Staphylococcus sp., Planococcus maritimus, and Vibrio aginolyticus were also isolated, suggesting their potential in bioremediation of contaminated sites.

Keywords Bacillus sp. · Bacterial resistance . Contamination $\cdot$ Heavy metals $\cdot$ Port areas

\section{Introduction}

A major concern nowadays is the impact of heavy metalrelease into natural environments by man [1]. This kind of pollution has ecological consequences and presents a serious risk to human health because heavy metals are ubiquitous and very persistent pollutants [2].

The marine environment is often a dump site for contaminated wastewater produced by many industries. It is also the location of oil exploration and active harbors, and it is crossed by transport routes of large ships. All of these activities can generate heavy metal contamination [3]. Losses, leaks, and spills occur during loading and unloading of transport vessels, during materials storage, during chemical transfers, upon washing of isocontainers, and during maintenance of wash bays, and during commercial leaching [4].

Thus, the interest over the impacts of heavy metals on the marine environment is a growing area of scientific research. In the sea, these contaminants largely accumulate in the sediment, and their deposition generates toxicity to aquatic biota including microorganisms, which are present in the sediment $[5,6]$.

Heavy metals play an important role in processes involving microorganisms in sediments. Metals such as calcium, zinc, nickel, iron, potassium, magnesium, manganese, and cobalt 
are essential nutrients at low concentrations. These elements participate in biochemical catalysis, acting as protein and nucleic acid stabilizers, and enzyme cofactors, and participating of several biological processes in the cell as osmotic balance, oxidative phosphorylation, motility, and regulation of membrane channels activity $[7,8]$.

High metal concentrations are toxic to microorganisms due to their abilities to affect conformational changes on the structure of nucleic acids and proteins, and also could interfere in several biological processes [7]. Abiotic stress caused by metals can affect the growth, morphology, and metabolism of bacteria $[9,10]$. Consequently, heavy metals can change the size, composition, and activity of the microbial community [11], altering, as well, the bacterial densities and diversity [6], which is worrisome, once marine microorganisms are of critical importance to the health of the environment, and the life on the planet. They are integral to all major biogeochemical cycles, fluxes, and processes that occur in marine systems where elements move between oxidized and reduced forms. Microorganisms are extremely abundant and diverse, and they play a key role in the regulation of the earth's climate [12]. Marine microorganisms also provide essential goods and services to human societies through their production of oxygen, their support of a sustainable food supply, and their part in regulating the health of the marine environment [13]. Bacteria are also the first step in the transfer of toxic compounds to higher trophic levels of the food chain [14].

Bacteria have developed several defense mechanisms to combat stress caused by heavy metals. These mechanisms include metal-complex formation, reduction of certain metals to less toxic species, or efflux of the metals from the cell $[15,16]$.

Because these microorganisms are able to transform these toxic compounds into less toxic or non-toxic, they are potentially useful in bioremediation of contaminated soils and sediments [17]. Such application is especially useful with marine bacteria, which live in the extreme environments conditions and can be utilized in situ [18].

Studies to detect, isolate, and monitor the occurrence of bacteria that are resistant to heavy metals in the marine environment are relatively recent and scarce, particularly in Brazil, but studies on marine areas in several countries have shown the importance of the presence of these bacteria in marine environments [12, 19, 20].

Some studies show that heavy metal discharge into the environment not only causes selection of heavy metalresistant bacteria but may also cause selection of antibioticresistant bacteria. This occurs because some mechanisms for heavy metal resistance function in a similar way of those for resistance to antibiotics. Thus, an environmental problem involving heavy metal contamination may become a public health issue [12].
These results reflect the importance of studies on heavy metal-resistant bacteria in coastal and estuarine areas, particularly in areas that receive domestic and industrial sewage and waste from harbor activities. Several regions of Brazilian coast are chronically contaminated by untreated sewage discharge that brings to coastal waters various substances, including heavy metals. An example of a contaminated region is the area in which the Port of São Sebastião is located [4]. Additionally, in these areas, the problem is compounded by the presence of tourist routes, high population densities. At the same time, there is the presence of rich and important biodiversity. For these reasons, studies on heavy metal-resistant bacteria in polluted areas are very important.

Therefore, this study aimed to isolate and identify heavy metal-resistant bacteria in Araça Bay and São Sebastião Channel sediments to test the hypothesis that activities that contribute for heavy metal disposal and the increase of metals concentrations in environment, like harbors and sewage discharge, can influence in density, diversity, and distribution of heavy metal-resistant bacteria.

\section{Material and Methods}

\section{Study Area}

Araça Bay is located in the city of São Sebastião, in north coast of São Paulo State, southeastern Brazil, in an area adjacent to the Port of São Sebastião. This port is of significant economic importance to the country. Its natural setting places it as the third best port in the world [21].

Araça Bay includes ecosystems such as rocky shores, sandy beaches, and mangroves. It is part of a sublittoral zone that extends into the São Sebastião Channel. It also has widespread biological diversity [22].

Because of the proximity of urban human developments, this set of different ecosystems is exposed to different types of human activity, including illegal occupation and waste dumping. The bay adjoins the Port of São Sebastião and the Petrobras Waterway Terminal, where there are frequent oil spills and other complications. In addition, there is a proposal to expand the harbor on Araça Bay, threatening all its biodiversity [22].

One of the largest oil terminals in Brazil is located in the center of this region. At the Araça Bay, a marine outfall is located, by which almost all domestic sewage from the city of São Sebastião is discharged [23].

\section{Sample Collection and Analysis}

Sediment samples were collected quarterly using a corer (10 cm of length) at 37 sites along the Araça Bay during 1 year. The Araça Bay was divided in two sample regions: the 
intertidal zone and the sublittoral zone (Fig. 1). The intertidal zone is dominated by a tidal regime and is exposed during low tide. The sublittoral zone is not exposed during low tide, has a greater depth, and is more dominated by currents [24].

For each collection station, the sample of $10 \mathrm{~g}$ of sediment was added to $90 \mathrm{~mL}$ of saline solution, homogenized, and serially diluted to $10^{-5}$. From the serial dilutions, $1 \mathrm{~mL}$ of the $10^{-3}$ and the $10^{-5}$ dilutions was inoculated into Marine Agar 2216 (MA, Difco) and plated using the pour plate method. All plates were prepared in triplicate. Inoculated plates were incubated at $28^{\circ} \mathrm{C}$ for $48 \mathrm{~h}$. The colonies were counted and the densities were expressed as colony-forming units per gram of sediment ( $\mathrm{CFU} \mathrm{g} \mathrm{g}^{-1}$ ).

One hundred colonies were randomly selected and subcultured three successive times under the same culture conditions. Resistance testing was then applied to these isolated and purified colonies. Each colony isolated was tested for heavy metal resistance by determining the minimum inhibitory concentrations (MIC). The MICs of four different heavy metals $(\mathrm{Cd}, \mathrm{Cr}, \mathrm{Cu}$, and $\mathrm{Zn})$ were determined for each isolate using Mueller-Hinton agar (Difco), which contained each metal in concentrations ranging from 12.5 to $3200 \mu \mathrm{g} \mathrm{mL}^{-1}$. The four heavy metals were tested in the following form: $\mathrm{CdSO}_{4} \cdot 8 / 3 \mathrm{H}_{2} \mathrm{O} ; \mathrm{ZnSO}_{4} \cdot 7 \mathrm{H}_{2} \mathrm{O} ; \mathrm{CuSO}_{4}$. $5 \mathrm{H}_{2} \mathrm{O} ; \mathrm{K}_{2} \mathrm{CrO}_{4}$ (Merck). The isolates were considered resistant if the MICs exceeded that of the control organism. Escherichia coli K-12 ATCC 25922 and Staphylococcus aureus ATCC 29213 strains were used as controls organisms $[25,26]$. The isolates that were found to be resistant to the heavy metals were then molecularly identified.

After identification, an average of the minimum inhibitory concentration of each species was made.

\section{Identification by Microbiological and Molecular Biology Approaches}

After initial characterization by colony morphology, each isolate was then identified on the basis of 16S rRNA gene sequencing. For this purpose, each isolate was grown in Nutrient Broth prepared with sterile and filtered seawater. Its genomic DNA subsequently extracted using the PureLiink ${ }^{\circledR}$ Genomic DNA Kit (Thermo Fisher Scientific). The DNA was extracted following the recommendation of the manufacturer. The DNA integrity was checked by agarose gel electrophoresis $(0.8 \%$ in TAE $1 \times$, containing $10 \mu \mathrm{M}$ of ethidium bromide) and the samples were quantified spectrophotometrically. Gene amplification was carried out using previously published oligonucleotides sequences: 27S-F (5'-CAAGAGTTTGATCC TGGCTCAG-3') and 1492-R (5'-GGTTACCTTGTTAC GACTT-3'). The polymerase chains reactions consisted in: $1 \times$ PCR buffer (Invitrogen, Milan, Italy), $1.5 \mathrm{mM} \mathrm{MgCl}_{2}$, $0.25 \mathrm{mM}$ of each dNTP, $15 \mathrm{pmol}$ of each oligonucleotide, $100 \mathrm{ng}$ of genomic DNA, and $1 \mathrm{U}$ of Taq polymerase in a final volume of $50 \mu \mathrm{L}$. Initial denaturation at $94{ }^{\circ} \mathrm{C}$ for $5 \mathrm{~min}$ was followed by 30 cycles consisting of denaturation at $94{ }^{\circ} \mathrm{C}$ for $1 \mathrm{~min}$, annealing at $55^{\circ} \mathrm{C}$ for $1 \mathrm{~min}$, and extension at $72^{\circ} \mathrm{C}$ for $2 \mathrm{~min}$. A final extension at $72{ }^{\circ} \mathrm{C}$ for $10 \mathrm{~min}$ was used. The amplification of was checked by agarose gel electrophoresis, as described before, and PCR products were purified using the PureLink ${ }^{\circledR}$ Quick Gel Extraction and PCR purification Combo Kit (Thermo Fisher Scientific)

\section{DNA Sequencing and Data Analysis}

Purified PCR product (50 ng) was used to cycle sequence the DNA using the ABI Prism BigDye terminator cycle sequencing kit (Thermo Fisher Scientific), following the conditions suggested by the manufacturer and using 5 pmol of the oligonucleotides $27 \mathrm{~S}-\mathrm{F}$ or $1492-\mathrm{R}$. Then the samples were injected in the ABI 310 automated sequencer (Thermo Fisher Scientific). The chromatograms were evaluated using the Chromas software (twww.technelysium.com.au) and analyzed using BioEdit software [27]. The 16S rRNA gene sequences ( $\sim 1360$ nucleotides) were assembled from multiple readouts (using the forward and reverse primers) and compared to nucleotide sequences of the NCBI GenBank using the Blastn (http://blast.ncbi.nlm.nih.gov) to the organisms' identification. The multiple sequence alignments were performed using Clustal Omega [28] Columns and the gaps were removed. The final tree was obtained using MEGA 6 [29]. The sequences were assigned to species using the highest-scoring sequence for which species information was available when the sequence similarity was greater than $97 \%$.

\section{Evaluation of the Heavy Metal Concentrations and Organic Matter Content}

To determine the organic matter content of the sediment samples, $100 \mathrm{~g}$ of each sample was dried at $105^{\circ} \mathrm{C}$ and then heated to $250^{\circ} \mathrm{C}$ for $5 \mathrm{~h}$. Next, the dried sample was weighed, and the difference between the initial and final weight was determined. The weight difference was used as a measure of the organic matter content of the sediment.

Four heavy metal for analyses, chromium $(\mathrm{Cr})$, copper $(\mathrm{Cu})$, cadmium $(\mathrm{Cd})$, and zinc $(\mathrm{Zn})$, were chosen. These metals were chosen because they present significant concentrations in Brazilian coastal waters near harbors and industrial areas [30]. To analyze the concentration of these metals, sediment samples were frozen and lyophilized according to the SW 846 method 3051 from the EPA [31]. Metals were quantified using inductively coupled plasma atomic emission spectroscopy (ICP-AES). Certified reference materials (CRMs) EnviroMAT SS-1 and EnviroMAT SS-2 (SCP Science) were used as stoichiometry standards in elemental analysis. 


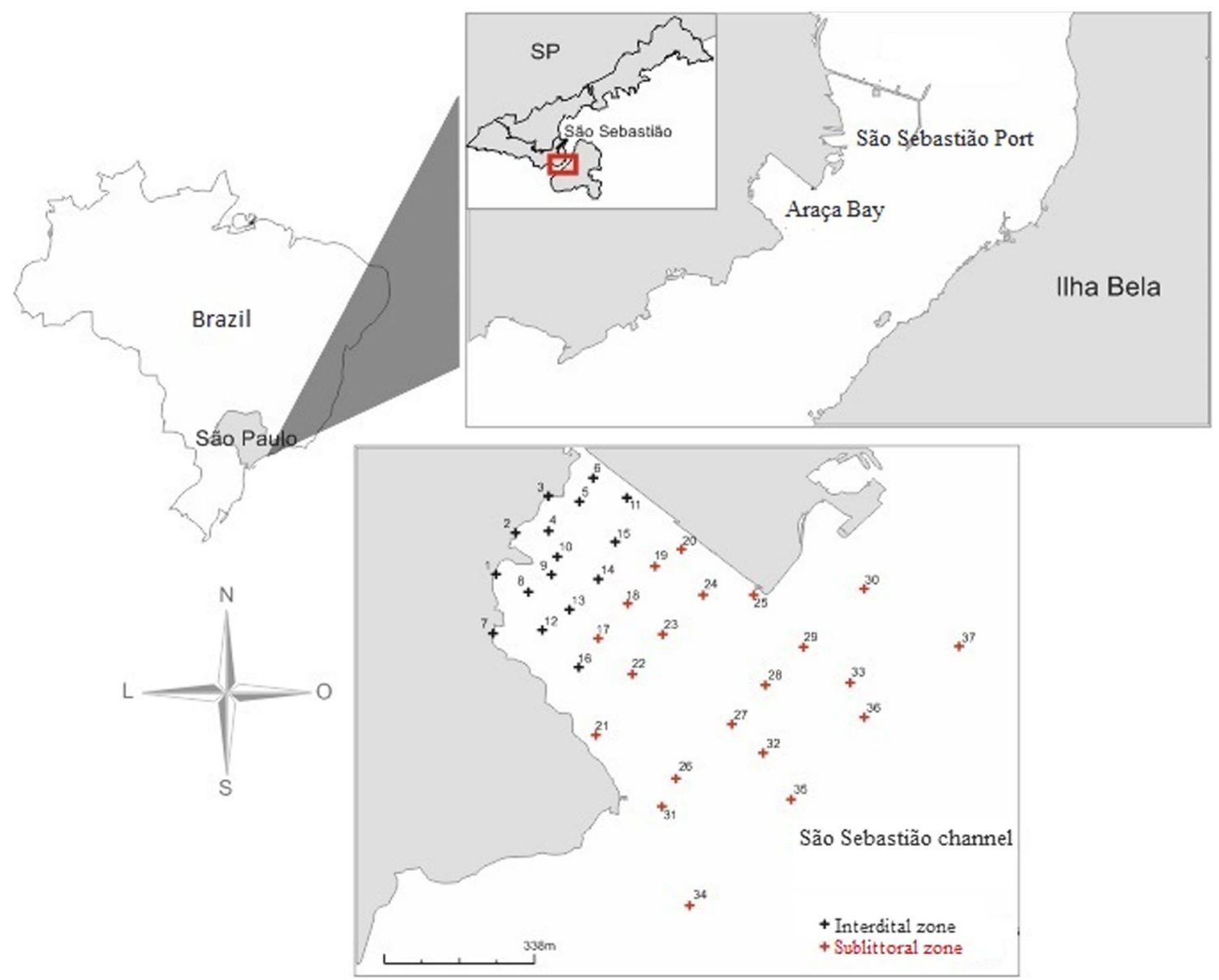

Fig. 1 Map of São Sebastião region showing the location of the São Sebastião Channel and the Araça Bay in detail with the sampling sites located in the sublittoral zone [1-16] and in the intertidal zone [17-37]

\section{Statistical Analyses}

Statistical analyses were conducted using " $\mathrm{R}$ " version 2.5.0. All the environmental and biological parameters were analyzed in order to evaluate normality through a Shapiro-Wilk test (SW) and equality of variances through a Levene test (L). Data with not normal distribution and heteroscedasticity was compare using Mann-Whitney non-parametric test for independent samples and correlation was made using Spearman correlation. To analyze frequency of heavy metal resistance strains, the Chi square test was used. Finally, a multivariate analysis was made using Principal Components Analysis (PCA) (Past3).

\section{Results}

\section{Bacterial Abundance, Percentage of Organic Matter, and Metal Concentration in Sublittoral and Intertidal Zones}

The bacterial concentration varied among the stations, especially among those from the sublittoral zone.
Maximum values reached $8510^{4} \mathrm{CFU} \mathrm{g}^{-1}$. The lowest values were between 7 and $10^{4} \mathrm{CFU} \mathrm{g}^{-1}$. Cell concentrations were significantly higher in the sublittoral zone $(p=0.000025)$ (Fig. 2).

The percentage of organic matter in the sediment ranged from 4.9 to $14.8 \%$. The highest peaks were recorded at points within the sublittoral zone, which had an average percentage of $13.7 \%$. Meanwhile, the average among the points within the intertidal zone was $6.5 \%$ $(p=0.002)$. The metal with the highest concentration in the sediment was $\mathrm{Zn}$ : its average concentration was $38.84 \mathrm{mg} \mathrm{kg}^{-1}$. It was followed by $\mathrm{Cr}$ at $19.8 \mathrm{mg} \mathrm{kg}^{-1}$, $\mathrm{Cu}$ at $5.47 \mathrm{mg} \mathrm{kg}^{-1}$, and $\mathrm{Cd}$ at $0.25 \mathrm{mg} \mathrm{kg}^{-1}$ (Fig. 3). All metal concentrations tested were significantly higher in the sublittoral zone $(\mathrm{Cd}: p=0.0088 ; \mathrm{Cr}: p=0.002 ; \mathrm{Cu}$ : $p=0.037$; and $\mathrm{Zn}: p=0.049$ ).

Since Brazil has no legislation concerning the heavy metal concentrations in sediment that are able to produce harmful effects on the biota and in the surrounding ecosystem in this study, we used the reference values of Canadian Sediment Quality Guidelines (SQG) for marine sediments [32] (Table 1). 


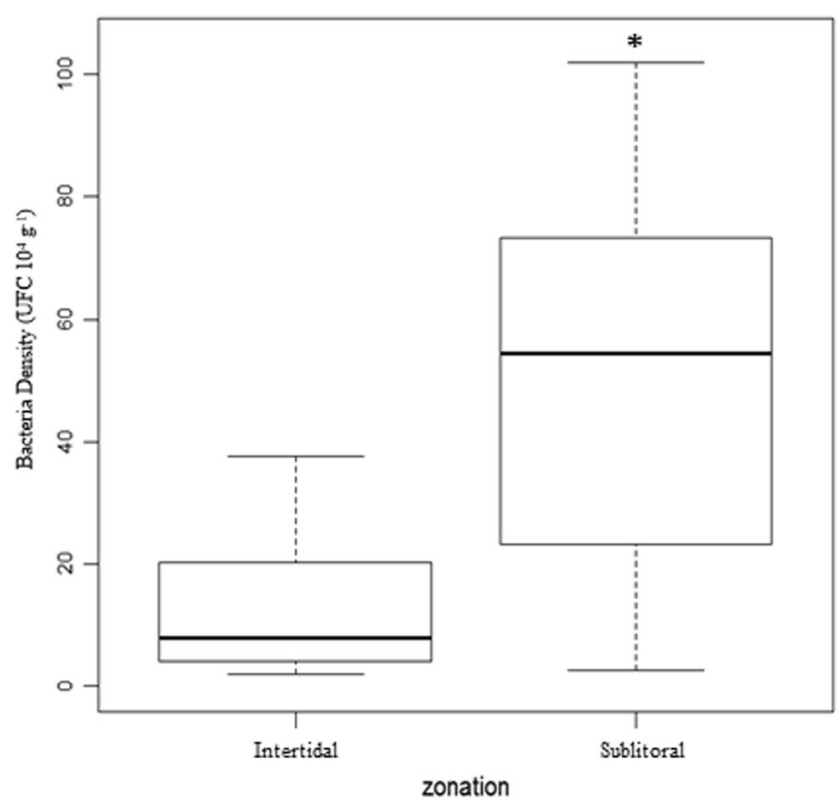

Fig. 2 Average bacterial density in the sublittoral zones and intertidal zones. Where black line $=$ mean; box $=$ mean \pm standard error; whiskers $=$ mean $\pm 5 \%$ confidence interval; and symbol (asterisk) $=$ represents statistical difference $(p<0.05)$

\section{Evaluation of the Resistance from Isolated Bacterial Strains to Heavy Metals}

Out of 100 isolated strains (50 from intertidal zone and 50 from sublittoral zone), $53 \%$ were resistant to chromium, $52 \%$ to zinc, $38 \%$ to cadmium, and $10 \%$ to copper (Fig. 4). The bacteria were more resistant to the metals that were present at higher concentrations $(\mathrm{Cr}$ and $\mathrm{Zn})$ in the study region. However, despite the low concentration of $\mathrm{Cd}$ in the sediment, a significant percentage of resistant strains were found.

The tolerance of the isolated bacterial strains for each heavy metal tested is shown in Table 2. Few strains tolerated $\mathrm{Cd}$ concentration levels greater than $200 \mu \mathrm{g} \mathrm{mL}^{-1}$. In the case of $\mathrm{Cr}, 36 \%$ of the strains even grew at a concentration of $3200 \mu \mathrm{g} \mathrm{mL}{ }^{-1}$. In respect to $\mathrm{Zn}$ and $\mathrm{Cu}$, few strains (4 and $2 \%$, respectively) tolerated $1600 \mu \mathrm{g} \mathrm{mL}^{-1}$, and none were able to tolerate the highest concentration (3200 $\left.\mu \mathrm{g} \mathrm{mL}^{-1}\right)$.

A multi-resistance profile of each strain was also evaluated. Our results revealed that only $23 \%$ of the strains were susceptible to any heavy metal tested, $49 \%$ were resistant to more than two heavy metals simultaneously, and $7 \%$ of the bacteria were resistant to all four metals $(\mathrm{Cd}, \mathrm{Cu}, \mathrm{Cr}$, and $\mathrm{Zn})$. A higher percentage of metal-resistant bacteria were found in the sublittoral zone (note that this is also the zone in which the highest concentrations of metals were found). Only the correlation with cadmium was reverse. In the intertidal zone, both a lower concentration of metals and a smaller percentage of resistant strains were observed (Fig. 4).
In the sublittoral zone, bacteria were more resistant to $\mathrm{Zn}$, $\mathrm{Cu}$, and $\mathrm{Cr}$, whereas in the intertidal zone, the strains were more resistant to $\mathrm{Cd}$ and $\mathrm{Cr}$ (Fig. 4). Note that all higher heavy metal concentrations occur in the sublittoral zone when resistance to $\mathrm{Zn}$ and $\mathrm{Cu}$ was considered ( $\mathrm{Zn}: p=0.0077, \mathrm{X} 2=7.1$, $\mathrm{df}=1 ; \mathrm{Cu}: p=0.0003, \mathrm{X} 2=13.31 ; \mathrm{df}=1)$.

\section{Spatial Distribution of the Heavy Metals and Resistant Strains}

We also investigated the correlation between the metalresistant bacteria and the heavy metal concentration within the sampling areas. Figure 5 shows the maps of metal concentration distribution in the sampled areas within the São Sebastião Channel and the Araça Bay. The sampling sites in the sublittoral zone are numbered 1-16, and those in the intertidal zone are numbered 17-37. Notice that all higher heavy metal concentrations were in the sublittoral zone, which is most influenced by the harbor.

This pattern is very similar to that of $\mathrm{Zn}$ - and Cr-resistant bacteria, which are present in higher numbers in the areas where the concentrations of these metals are more abundant. In the case of Cd-resistant bacteria, this relationship is reversed (Fig. 6).

\section{Multivariate Analysis}

Now it is possible to see in Fig. 7 how all variables influence in each other. To confirm which factor influenced the most in explaining the data, a PCA was performed. It was possible to notice that heavy metals concentration had a clear influence in heavy metal-resistant bacteria in sediment. Only for $\mathrm{Cd}$ that this relationship was inverse. The components 1 and 2 demonstrated higher strength explaining together $76 \%$ of the variance (56.8 and 19.5, respectively).

\section{Evaluation of the Bacterial Strains Abundance by $16 \mathrm{~S}$ rRNA Subunit Gene Analysis}

The genetic molecular analysis from the gene of 16S rRNA subunit allowed revealed the prevalence of Bacillus sp. out of the 50 strains isolated in this study. Quantitatively, only four species account to $\sim 75 \%$ of the bacterial identified in this work. Bacillus pumilus occurred most frequently in the samples (38\%), followed by the Bacillus cereus (18\%), Vibrio alginolyticus (10\%), and Planococcus maritimus (8\%). The abundance of other bacteria varied from $2 \%$ (Bacillus thuringiensis, Bacillus safensis, and Bacillus boroniphilus) to $3 \%$ (Bacillus aerophilus, Enterobacter asburiae, Exiquobacterium sp, Micrococcus luteus, S. aureus, Staphylococcus sp, Staphylococcus epidermidis, Staphylococcus warneri) (Fig. 8). 

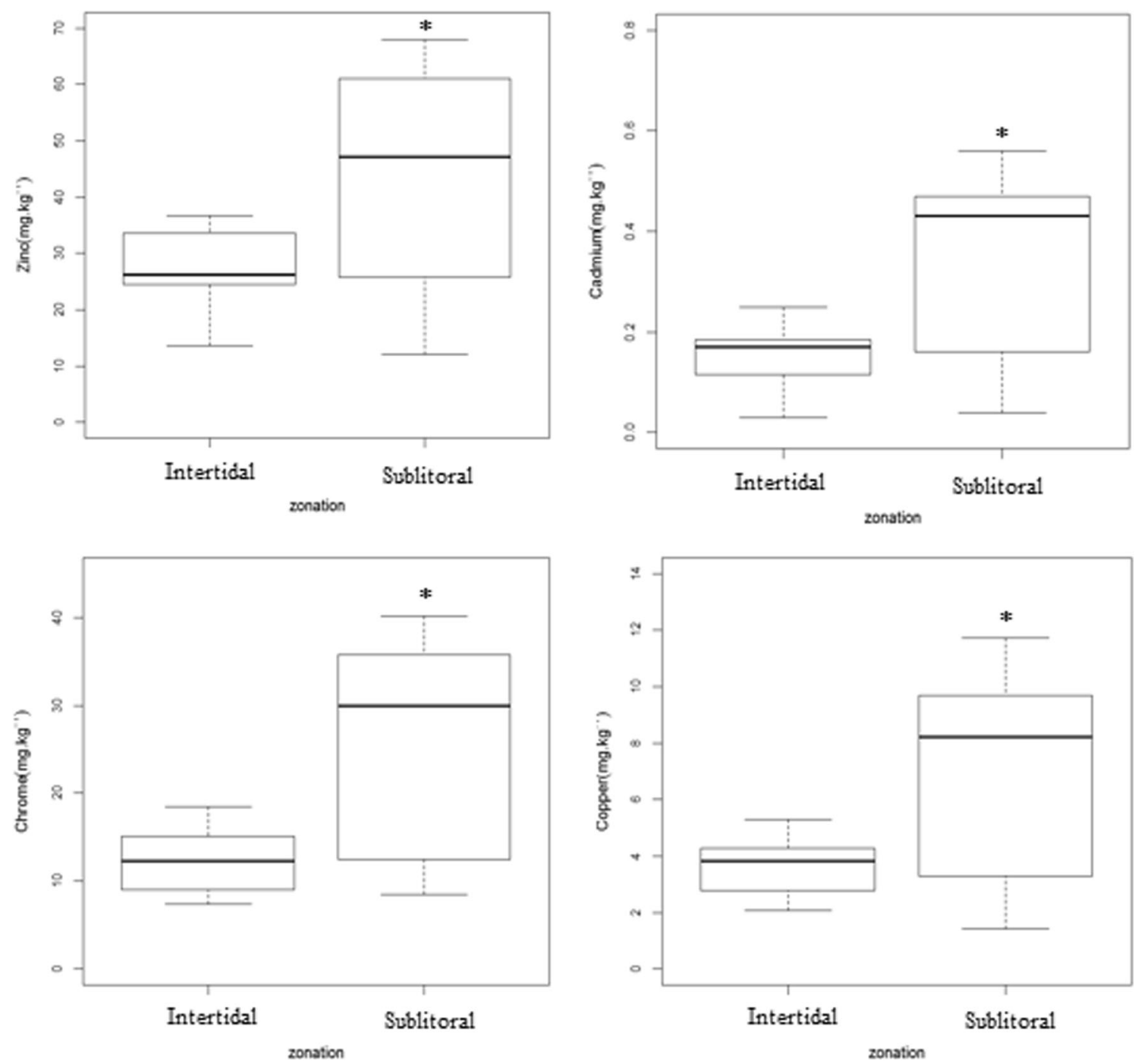

Fig. 3 Heavy metal concentrations $\left(\mathrm{mg} \mathrm{kg}^{-1}\right)$ : zinc (a), cadmium (b), copper (c), and chromium (d) from two sampling zones (intertidal and sublittoral). Where black line $=$ mean; box $=$ mean \pm standard error;

\section{Minimum Inhibitory Concentration Analysis}

Each genus responded differently to the heavy metals tested in this study when MIC was considered. In the case of zinc,

Table 1 References values for heavy metal concentrations in estuarine sediments as per the Canadian Sediment Quality Guidelines (SQG)

\begin{tabular}{lll}
\hline Metal & TEL $\left(\mathrm{mg} \mathrm{kg}^{-1}\right)$ & PEL $\left(\mathrm{mg} \mathrm{kg}^{-1}\right)$ \\
\hline $\mathrm{Zn}$ & 124.0 & 271.0 \\
$\mathrm{Cr}$ & 52.3 & 160.0 \\
$\mathrm{Cu}$ & 18.7 & 108.0 \\
$\mathrm{Cd}$ & 0.7 & 42 \\
\hline
\end{tabular}

TEL threshold effect level, $P E L$ probable effect level

Enterobacter sp. and Exiquobacterium sp. exhibited the highest average MIC $\left(1600 \mu \mathrm{g} \mathrm{mL}^{-1}\right)$. The lowest MIC (12.5 $\mu \mathrm{g} \mathrm{mL}^{-1}$ ) was exhibited by Micrococcus sp. (Fig. 9a).

All genera presented high MICs of chromium. Exiquobacterium sp. reached $3200 \mu \mathrm{g} \mathrm{mL}^{-1}$, followed by Bacillus sp., Vibrio sp., and Staphylococcus sp., whose MICs were similar and ranged from 2400 to $2614 \mu \mathrm{g} \mathrm{mL}^{-1}$ (Fig. 9b). Enterobacter sp. had the highest MIC of copper $\left(1600 \mu \mathrm{g} \mathrm{mL}^{-1}\right)$. The other genera exhibited values ranging from 250 to $568 \mu \mathrm{g} \mathrm{mL}^{-1}$ (Fig. 9c).

Cadmium was the metal with the lowest MIC among the strains. The highest peak was obtained by Micrococcus sp. $\left(400 \mu \mathrm{g} \mathrm{mL}^{-1}\right)$, while the lowest peak was obtained by Exiquobacterium sp. $\left(12.5 \mu \mathrm{g} \mathrm{mL} \mathrm{m}^{-1}\right)$. Concentrations among the other genera ranged from 200 to $249 \mu \mathrm{g} \mathrm{mL}^{-1}$ (Fig. 9d). 
Fig. 4 Percentage of strains found to be resistant to the heavy metals tested (cadmium, copper, chromium, and zinc) in the intertidal zone and the sublittoral zone. The symbol (asterisk) represents statistical differences

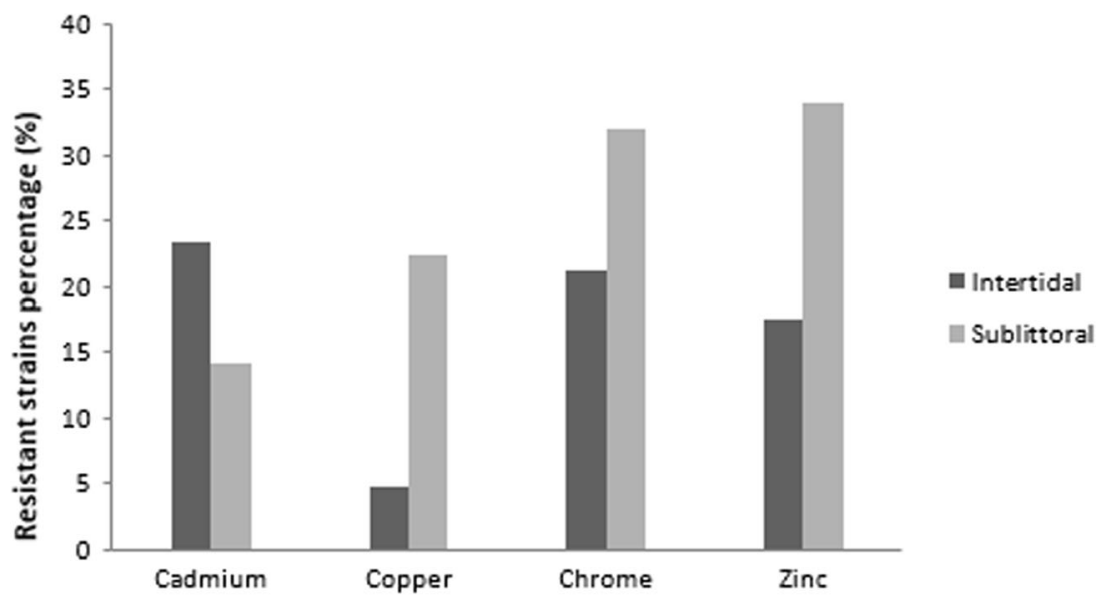

\section{Discussion}

The sediment has been considered to be a layer of the water column in which pollutants accumulate because of its high adsorption and storage capacities. In the sediment, pollutant concentrations are found to be several orders of magnitude higher than those found in water. Sediments are therefore good indicators both of acute and chronic pollution [33].

The heavy metal concentrations determined in most of the samples were below the values established by Canadian law. However, in some parts of the sublittoral zone, the levels obtained were above the limits. These levels are likely because of the nearby refineries, fossil fuel burning, and industrial and domestic effluent discharge, all of which end up influencing $\mathrm{Zn}, \mathrm{Cr}, \mathrm{Cd}$, and $\mathrm{Cu}$ concentrations found in these sediments [34].

In the present study, the highest metal concentrations were observed in the sublittoral zone. The collection stations in the sublittoral zone are near or even within the São Sebastião channel, where pollution originating mostly from the harbor, domestic, and industrial effluents occurs. The local hydrodynamics also allow the high accumulation of metals and organic matter in the sublittoral zone. Castro-Filho [35] and Fontes [36] showed that the circulation of the São Sebastião channel is characterized by northerly and southerly movements, with day-long intervals and little influence from tidal currents. This indicates that part of the pollution coming from the northern part of the channel, where the harbor and the Almirante Barroso Waterway Terminal (TEBAR) are located, may have an influence on the deposition of heavy metals into the sediments of the Araça Bay.

Already in 1977, it was found that bacteria in marine environments undergo selection or adjustment when heavy metals are present [37]. It has also been found that heavy metals can change the size, composition, and activity of the microbial community [11]. Abiotic stress caused by metals can affect the growth, morphology, and metabolism of bacteria $[9,10]$.

In the current study, however, the highest density of bacteria was found in the sublittoral zone, in which the metal concentrations are higher. This fact can be explained by the presence of wastewater discharge close to the sublittoral zone, where there is a high organic matter concentration that favors bacterial growth. Another likely factor is that the highest densities of bacteria occur in areas with higher concentrations of metals because most of the bacteria present there are already resistant as a result of chronic contamination [20].

Generally, metal contaminations in the environment cause an increase in the level of resistance among the local bacterial community [38] and reduce the bacterial diversity as a consequence of bottleneck events [39]. Therefore, the higher the heavy metal concentration, the higher will be the occurrence of heavy metal-resistant bacteria. This finding was confirmed in this study for in the case of $\mathrm{Zn}$ and $\mathrm{Cr}$. The higher concentration of these two metals in sediments also presented more
Table 2 Heavy metal tolerance among bacteria isolated from Araça Bay sediment

\begin{tabular}{llllllllllll}
\hline Metal & \multicolumn{1}{l}{$\begin{array}{l}\text { Percentage }(\%) \text { of tolerant isolated strain at different } \\
\text { metal concentrations }\left(\mu \mathrm{gL}^{-1}\right)\end{array}$} \\
\hline & 12.5 & 25 & 50 & 100 & 200 & 400 & 800 & 1600 & 3200 & $>3200$ & $\begin{array}{l}\text { Resistant } \\
\text { isolates (\%) }\end{array}$ \\
Cadmium & 54.0 & 51 & 49 & $38^{\mathrm{a}}$ & 22 & 7 & 0 & 0 & 0 & 0 & 38 \\
Copper & 100 & 95 & 94.1 & 86 & 42 & 25 & $10^{\mathrm{a}}$ & 2.0 & 0 & 0 & 10 \\
Cadmium & 100 & 100 & 100 & 100 & 100 & 97.0 & 65.8 & $53^{\mathrm{a}}$ & 36.0 & 0 & 53 \\
Zinc & 100 & 96.0 & 94.0 & 93.0 & 72.0 & $52^{\mathrm{a}}$ & 42 & 4 & 0 & 0 & 52 \\
\hline
\end{tabular}

${ }^{\text {a }}$ Minimal inhibition concentrations of standard strain E. coli $\mathrm{K} 12$ 

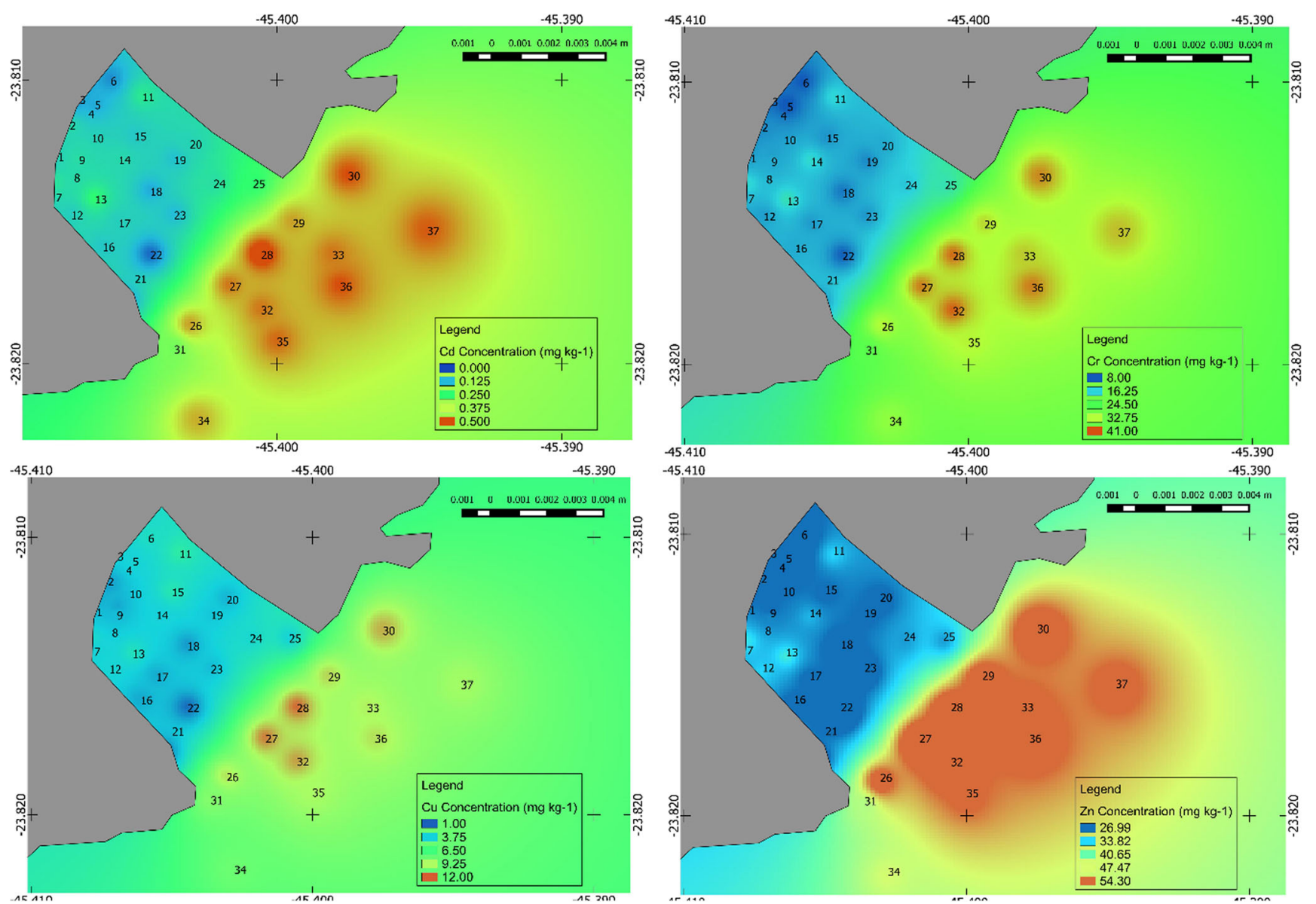

Fig. 5 Distribution of concentrations of $\mathrm{Cd}(\mathbf{a}), \mathrm{Cr}(\mathbf{b}), \mathrm{Cu}(\mathbf{c})$, and $\mathrm{Zn}(\mathbf{d})$ in sampled areas in the São Sebastião Channel and in the Araça Bay, with a sublittoral zone [1-16] and an intertidal zone [17-37]

than half of resistant strains identified in this work. $\mathrm{Cu}$ that was found at the lowest concentration presented the lowest percentage of resistant strains to $\mathrm{Cu}$.

In this study, more bacterial strains were resistant to chromium than to the other metals tested. This difference may be explained by the relatively low toxicity of chromium compared to the toxicity of the other metals. Chromium (and particularly $\mathrm{Cr}(\mathrm{VI})$ ) exhibits little biological activity because of low interaction with macromolecules and may be considered less toxic than other heavy metals [40].

It is well known that zinc is a trace element that is essential for bacterial cell growth, but it is a potent inhibitor of electron transport in cellular respiration when present at high concentrations [41]. However, its toxicity is very low compared to that of other metals such as $\mathrm{Hg}, \mathrm{Cd}, \mathrm{Cu}, \mathrm{Ni}, \mathrm{Co}$, and $\mathrm{Pb}$ [42]. This factor may explain the results obtained in this study, in which more than half of the strains of bacteria isolated from Araça Bay were resistant to $\mathrm{Zn}$.

The bacteria exhibited low resistance to $\mathrm{Cu}$. This difference may occur because this metal is associated with acute and chronic toxicity in bacteria, and because it strongly affects the enzyme system and essential cellular metabolism [43].
Of the bacterial strains, $38 \%$ were resistant to cadmium, despite the low concentrations of this metal in the sediments of the Araça Bay. In fact, several studies have reported the presence of bacteria that are tolerant of heavy metals, even at sites with very low heavy metal concentrations [44]. This difference can be explained by cadmium's toxicity. Cd is the most toxic metal for living organisms, and low doses have been found to have adverse effects on biota [32]. Low Cd concentrations are able to select resistant bacteria because higher concentrations are lethal [45].

The results of PCA analysis confirms the hypothesis proposed in this study, as well all the points discussed above. Higher bacteria resistance was found in areas with high concentration of heavy metals, except for $\mathrm{Cd}$ because of it is extremely toxicity. However, although the Fig. 2 has shown that intertidal zone, which had a lower heavy metal concentration in general, had a lower bacteria density, PCA showed that highest concentrations of metals reduce bacterial density in the marine environment.

Akinbowale, Peng, Grant, and Barton [25] found the same bacterial resistance to metals tested in this study. The resistance occurred in the following order: $\mathrm{Cu}>\mathrm{Cr}>\mathrm{Zn}>\mathrm{Cd}$. 

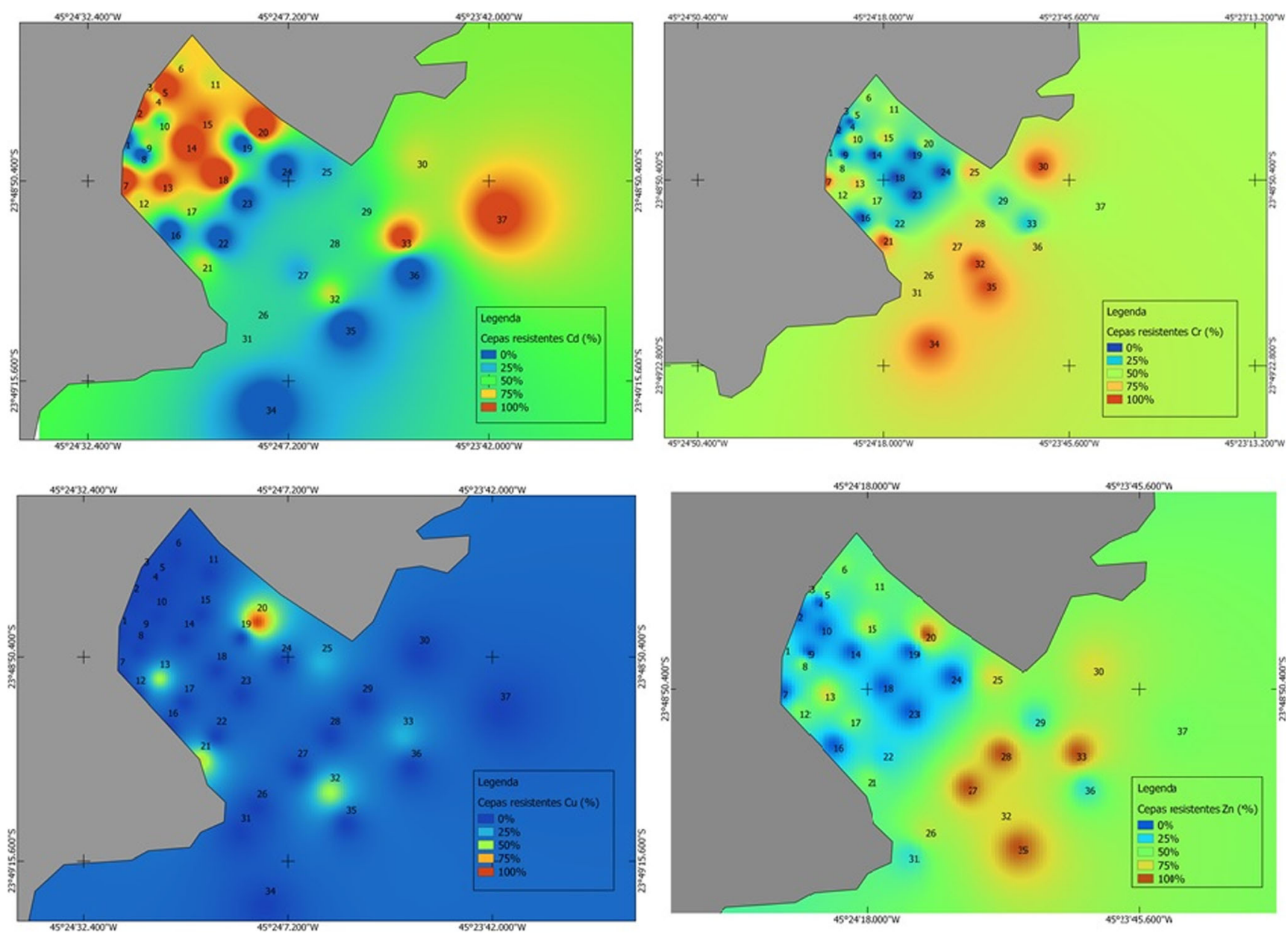

Fig. 6 Distribution of bacteria resistant to $\mathrm{Cd}(\mathbf{a}), \mathrm{Cr}(\mathbf{b}), \mathrm{Cu}(\mathbf{c})$, and $\mathrm{Zn}(\mathbf{d})$ in sampled areas in the São Sebastião Channel and in the Araça Bay, with the sublittoral zone [1-16] and the intertidal zone [17-37]

Matyar, Kaya, and Dinçer [46] studied the sediments of the Iskenderum Bay in Turkey and found bacteria to be more resistant to $\mathrm{Cd}$, followed by $\mathrm{Cu}$ and $\mathrm{Cr}$. This discrepancy suggests that there are differences in the heavy metal concentrations in sediments from different areas depending on the surrounding anthropogenic activities. These differences may be reflected in the bacterial resistance profile of the region.

MICs are important to understand the level of strains resistance and may be associated with the concentrations and toxicity of metals in the environment. Malik, Khan, and Aleem [38] isolated bacterial strains from the soil of industrial areas and reported highest $\mathrm{MIC}$ of $2400 \mu \mathrm{g} \mathrm{mL} \mathrm{L}^{-1}$ for $\mathrm{Cu}, \mathrm{Cd}, \mathrm{Zn}$, and $\mathrm{Cr}$. In this study, the MIC of almost all of the metals reached maximum values of $3200 \mu \mathrm{g} \mathrm{mL}^{-1}$. The exception was $\mathrm{Cd}$, the MIC of which reached a maximum value of $800 \mu \mathrm{g} \mathrm{mL}^{-1}$

Malik and Jaiswal [47] also found high MICs in their isolated strains and associated this result with sampling area location. Similar to the current study, Malik and Jaiswal [47] collected their samples from locations close to points of industrial and domestic effluent discharge. In the present study, the collection points were close to domestic sewage and industrial wastewater discharge points, and were also close of the São Sebastião Port and the TEBAR.

Thus, the distribution of resistant bacteria in the Araçá Bay may be associated with effluent discharge, since both the highest concentrations of metals and the higher percentages of resistant strains were found at the points of the sublittoral zone near the São Sebastião channel. These results also support the existence of higher heavy metal contamination in the São Sebastião channel.

Though the metal concentrations found in this study were below the reference values from Canadian Sediment Quality Guidelines (SQG) overall, a high frequency of resistant bacterial strains was also found. These results suggest that the heavy metals likely have effects on the biota, particularly in the sublittoral area. The findings also suggest that these populations of microorganisms are in the process of undergoing biological and genetic changes.

This fact is very important, since bacteria are the most abundant organisms in the sediment and represent the first 


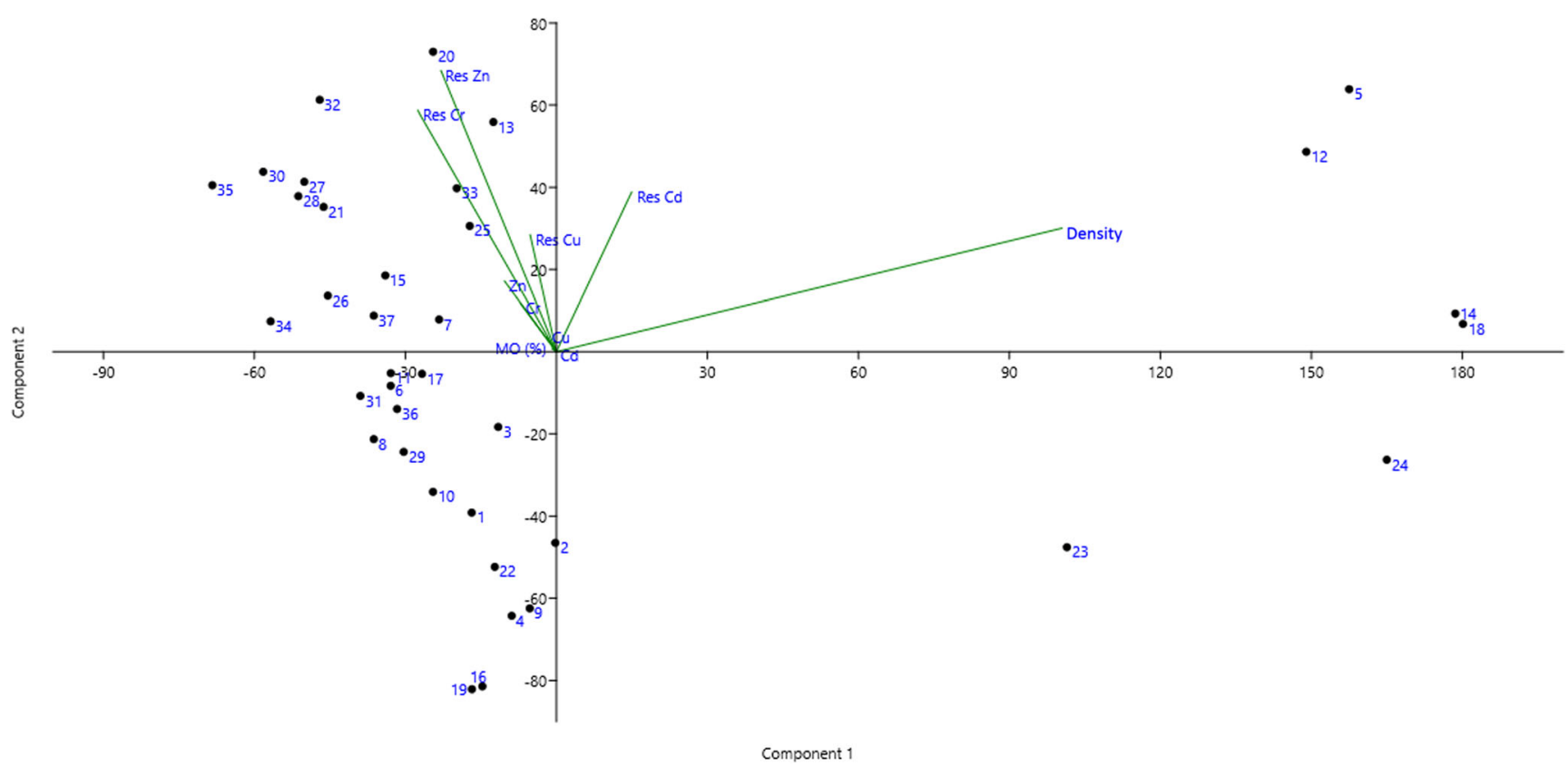

Fig. 7 Principal components analysis (PCA) of stations using variables: density; organic matter; $\mathrm{Zn}$ concentration $(\mathrm{Zn})$; $\mathrm{Cu}$ concentration $(\mathrm{Cu})$; $\mathrm{Cr}$ concentration $(\mathrm{Cr})$; Cd concentration $(\mathrm{Cd})$; percentage of resistant bacteria to $\mathrm{Zn}(\operatorname{Res} \mathrm{Zn}), \mathrm{Cu}(\operatorname{Res} \mathrm{Cu}), \mathrm{Cr}(\operatorname{Res} \mathrm{Cr})$, and $\mathrm{Cd}(\operatorname{Res} C d)$

steps of toxic component transfer to higher trophic levels [14]. Because of these factors, the results suggest the need for pollution monitoring in the Araça Bay.

A significant portion of the bacteria identified in this study belongs to the group of Gram-positive bacteria, which is similar to findings from other studies [20, 48, 49]. Previous studies estimated that only $5 \%$ of the bacteria found in the ocean was gram-positive [50], but more recent studies suggest that the abundance and diversity of Gram-positive in the sediments are much larger [49, 51, 52]. The present study suggests a higher abundance and diversity of gram-positive bacteria in Brazilian marine sediments.
The isolates were also identified. The frequency of Bacillus genus was substantially higher relative to the other genera. Bacteria resistant to heavy metals were isolated in several other studies with results similar to ours [53-55]. This consistency may indicate that Bacillus sp. possesses significant potential for the bioremediation of marine and estuarine areas polluted with heavy metals.

Kamala-Kannan and Lee [56] isolated bacteria resistant to heavy metals in sediments of the Sunshon Bay in South Korea. All isolates were identified as Bacillus sp. This finding suggests that anthropogenic pollution ultimately selects for resistant species. In this case, Bacillus sp.
Fig. 8 Percentages of bacterial species isolated from sediment samples and identified by the analysis of the $16 \mathrm{~S}$ rRNA subunit gene

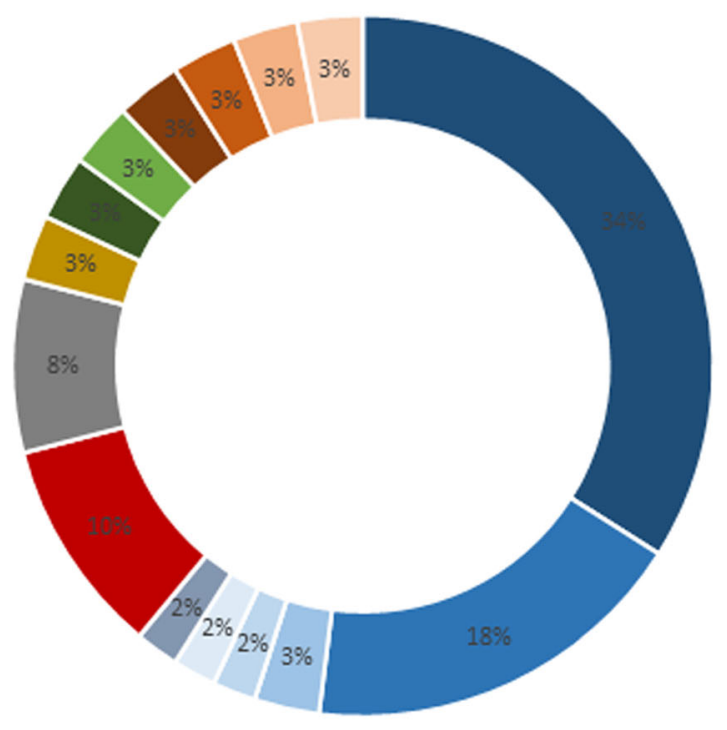

\author{
- Bacillus pumillus \\ - Bacilifus cereus \\ - Bacililus a erophilus \\ " Bacillus thurigiensis \\ Bacililus safensis \\ - Bacililus boroniphilus \\ - Vibrio alginolyticus \\ - Planococcus maritimus \\ - Micrococcus luteus \\ - Enterobacter asburiae \\ - Exiquobacterium sp \\ - Staphylococcus aureus \\ - Staphylococcus sp \\ " Staphylococcus epider mis \\ " Staphylococccus warneri
}


$\mathrm{Zn}$

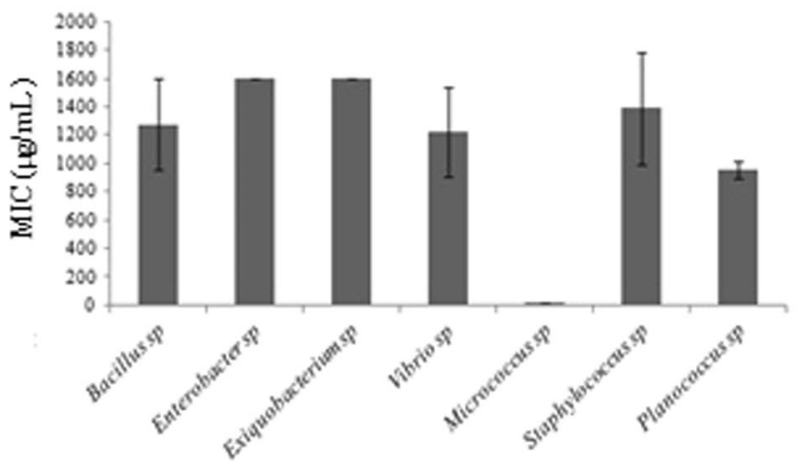

$\mathrm{Cu}$

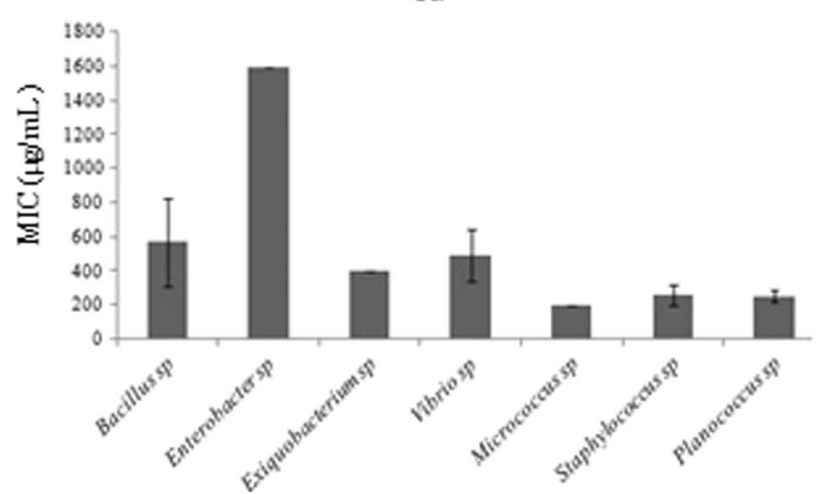

$\mathrm{Cr}$

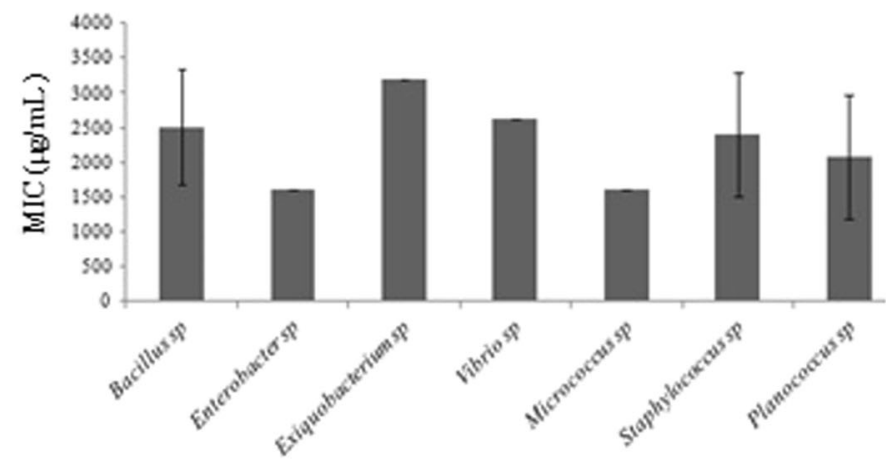

Cd

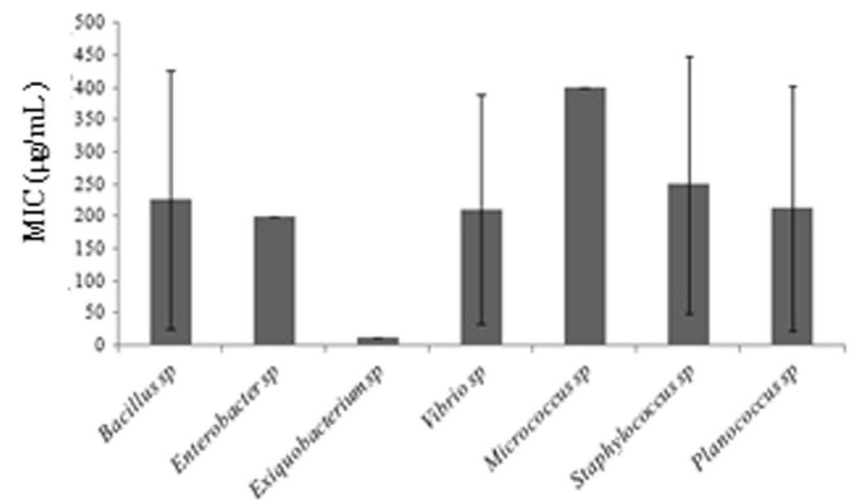

Fig. 9 Average minimum inhibitory concentration (MIC) of zinc (a), chromium (b), copper (c), and cadmium (d) for each bacterial genera isolated

was the dominant taxonomic group in the communities of heterotropic bacteria in the polluted areas.

Staphylococcus sp. is also a genus that may be used in bioremediation. Staphylococcus sp. may be resistant to multiple heavy metals, findings which are similar to those obtained in the present study [57]. Several species of Vibrio and $P$. maritimus were also isolated from marine sediments in other studies and exhibited resistance to various metals, as well as simultaneous resistance to antibiotics [20].

Pollution of the marine environment by effluents from factories, harbor activities, and other sources containing heavy metals selects for bacteria that are resistant to various metals. As a result, this pollution is a problem not only for the local biota but also for public health, since simultaneous resistance to metals and antibiotics is a reciprocal phenomenon [57].

Recently, the Scientific Committee on Emerging and Newly Identified Health Risks suggested that various biocides, including heavy metals, may contribute to the selection and maintenance of bacteria with antibiotic resistance [58]. This contribution may occur through the horizontal transfer of genetic elements carrying genes that confer resistance to antibiotics and biocides or that share the same resistance mechanisms [58-60].

This problem is exacerbated by the fact that many of these bacteria are pathogenic and can cause serious problems to humans. For example, $S$. aureus has become very relevant in recent decades in respect to nosocomial infection with high levels of morbidity and mortality; in most cases, its multidrug resistance makes treatment difficult [61]. Another example is B. cereus, which can cause serious food-borne illness [62].

This effect on public health is another factor that reflects the need for heavy metal contamination-monitoring in the environment. This contamination could lead to heavy metalresistant bacteria that are more likely to be resistant to antibiotics.

The points discussed support the hypothesis of this study. In Araça Bay there is a clear relationship between heavy metal concentration and selection of heavy metal-resistant bacteria. There are groups that dominated the environment like Bacillus sp. Some implications are particularly important: it was possible to isolate bacteria with great biotechnological potential; the monitoring of heavy metal pollution has to be encouraging due the impact in microbial population and to the possibility of pathogenic strains also be resistant to antibiotics.

\section{Conclusion}

In this way, this study showed that the presence of harbor activities increase heavy metals concentration that influence the distribution of resistant strains, selecting a larger number of bacteria resistant to various forms of heavy metals. In 
addition, it may alter the microbial community and ecosystem function. We isolate several species of heavy metals-resistant bacteria with high MIC that can be used for future studies of marine bioremediation of contaminated areas in Brazil. Moreover, we observed that there is a dominance of Bacillus $\mathrm{sp}$. in this area and it can have high resistance to metals tested that could be an indicator of heavy metal-contaminated areas.

Acknowledgments The authors would like to thank UNESP and all members of the Marine Microbiology Laboratory (MICROMAR) and of the Structural Molecular Biology Laboratory (LABIMES). The Brazilian agency known as the Coordination for the Improvement of Higher Education Personnel (CAPES) and São Paulo Research Foundation (FAPESP) are acknowledged for financial support: The Biota Araça Research Project (process number: 2011/50317-5), coordinated by Dr. Cecília Amaral.

\section{References}

1. Sun W, Zhou Q, Xie X, Liu R (2010) Spatial, sources and risk assessment of heavy metal contamination of urban soils in typical regions of Shenyang, China. J Hazard Mat 174:455-462. doi:10.1016/j.jhazmat.2009.09.074

2. Andrade S, Poblet A, Scagliola M, Vodopivez C, Curtosi A, Pucci A, Marcovecchio J (2001) Distribution of heavy metals in surface sediments from an Antarctic marine ecosystem. Environ Monit Assess 66:147-158

3. Teitzel GM, Parsek MR (2003) Heavy metal resistance of biofilm and planktonic Pseudomonas aeruginosa. Appl Environ Microbiol 69:2313-2320

4. Hortellani MA, Sarkis JES, Abessa DMS, Sousa ECPM (2008) Avaliação da contaminação por elementos metálicos dos sedimentos do estuário Santos-São Vicente. Química Nov. 31:10 19. doi:10.1590/S0100-40422008000100003

5. Yang H, Rose NL (2003) Distribution of Hg in six lake sediments core across the UK. Sci Total Environ 304:391-404. doi:10.1016 /S0048-9697(02)00584-3

6. Pinto AB, Pagnocca FC, Pinheiro MA, Fontes RF, Oliveira AJ (2015) Heavy metals and TPH effects on microbial abundance and diversity in two estuarine areas of the Southern-central coast of São Paulo State, Brazil. Mar Pollut Bull 96:410-417. doi:10.1016/j.marpolbul.2015.04.014

7. Poole RK, Gadd GM (1989) Metals: microbe interactions. IRL Press, Oxford, pp 1-37

8. Ji G, Silver S (1995) Bacterial resistance mechanism for heavy metals of environmental concern. J Indust Microbiol 14:61-75

9. Wang Y, Shi J, Wang H, Chen OL, Chen Y (2007) The influence of soil heavy metals pollution on soil microbial biomass, enzyme activity, and community composition near a copper smelter. Ecotox Environ Safat 67:75-81. doi:10.1016/j.ecoenv.2006.03.007

10. Oliveira A, Pampulha ME (2006) Effects of long-term heavy metal contamination on soil microbial characteristics. J Biosci Bioeng 102:157-161. doi:10.1263/jbb.102.157

11. Giller PS, Malmqvist B (1998) The biology of streams and rivers. Oxford University Press, New York

12. Matyar F (2012) Antibiotic and heavy metal resistance in bacteria isolated from the Eastern Mediterranean Sea coast. Bull Environ Contam Toxicol 89:551-556. doi:10.1007/s00128-012-0726-4

13. Glöckner FO, Stal LJ, Sandaa RA, Gasol JM, O'Gara F, Hernandez F, Labrenz M, Stoica E, Varela MM, Bordalo A, Pitta P (2012)
Marine microbial diversity and its role in ecosystem functioning and environmental change. In: Calewaert JB, McDonough N (eds) Marine Board Position Paper 17. Marine Board-ESF, Ostend, Belgium

14. Gillan DC, Danis B, Pernet P, Joly G, Dubois P (2005) Structure of sediment-associated microbial communities along a heavy-metal contamination gradient in the marine environment. Appl Environ Microbiol 71:679-690

15. Banerjee S, Gothalwal R, Sahu PK, Sao S (2015) Microbial observation in bioaccumulation of heavy metals from the ash dyke of thermal power plants of Chhattisgarh, India. Adv Biosc Biotechnol 6:131-138. doi:10.4236/abb.2015.62013

16. Outten FW, Outten CE, O'halloran T (2000) Metalloregulatory systems at the interface between bacterial metal homeostasis and resistance. In: Storz G, Hengge-Aronis RR (eds) Bacterial stress responses. ASM Press, Washington, D.C, pp 145-157

17. Hasin AA, Gurman SJ, Murphy LM, Perry A, Smith TJ, Gardiner PE (2010) Remediation of chromium(VI) by a methane-oxidizing bacterium. Environ Sci Technol 44:400-405. doi:10.1021 les901723c

18. Dash HR, Magdwani N, Chakraboryi J, Kumari S, Das S (2013) Marine bacteria: potential candidates for enhanced bioremediation. Appl Microbiol Biotechnol 97:561-571. doi:10.1007/s00253-0124584-0

19. Kacar A, Kocyigit A (2013) Characterization of heavy metal and antibiotic resistant bacteria isolated from Aliaga Ship Dismantling Zone, Eastern Aegean Sea, Turkey. Int J Environ Res 7:895-902

20. Nithia C, Pandian SK (2010) Isolation of heterotrophic bacteria from Palk Bay sediments showing heavy metal tolerance and antibiotic production. Microbiol Res 165:578-593. doi:10.1016/j. micres.2009.10.004

21. ANTAQ. Porto de São Sebastião. Available in: www.antaq.gov. br/portal/pdf/portos/2012/saosebastiao.pdf; Accessed in: 05/09 $/ 2015$.

22. Amaral ACZ, Migotto AE, Turra A, Svhaeffer-Novelly Y (2010) Araçá: biodiversidade, impactos e ameaças. Biota Neotropica 10:147. doi:10.1590/S1676-06032010000100022

23. Gubitoso S (2010) Influência de efluentes domésticos e petroquímicos em sedimentos e carapaças de foraminíferos do canal de São Sebastião, SP. Dissertação (Mestrado) - Instituto de Geociências, Universidade de São Paulo, São Paulo

24. Feng H, Han X, Zhang W, Yu L (2004) A preliminary study of heavy metal contamination in Yangtze River Interdital zone due to urbanization. Mar Poll Bull 49:910-915. doi:10.1016/j. marpolbul.2004.06.014

25. Akinbowale OL, Peng H, Grant P, Barton MD (2007) Antibiotic and heavy metal resistance in motile aeromonads and pesudomonads from rainbow trout (Oncorhynchus mykiss) farms in Australia. Int J Antimicrob Agents 30:177-182

26. Ansari MI, Malik A (2007) Biosorption of nickel and cadmium by metal resistant bacterial isolates from agricultural soil irrigated with industrial wastewater. Bioresour Techno 98:3149-3153

27. Embley TM, Stackebrandt E (1994) The molecular phylogeny and systematics of the actinomycetes. Annu Rev Microbiol 48:257-289

28. Sievers F, Wilm A, Dineen D, Gibson TJ, KarplusK LW, Higgins DG (2011) Fast, scalable generation of high-quality protein multiple sequence alignments using Clustal Omega. Mol Syst Biol 7: 539. doi: $10.1038 / \mathrm{msb} .2011 .75$

29. Tamura K, Stecher G, Peterson D, Filipski A, Kumar S (2013) MEGA6: molecular evolutionary genetics analysis version 6.0. Mol Biol Evol 30:2725-2729. doi:10.1093/molbev/mst197

30. Abessa DMS, Carr RS, Rachid BRF, Sousa ECPM, Hortelani MA, Sarkis JE (2005) Influence of a Brazilian sewage outfall on the toxicity and contamination of adjacent sediments. Mar Pollut Bull 50:875-885 
31. USEPA (United States Environmental Protection Agency) (1994) Method 3051. Microwave assisted cid digestion of sediments, sludges. Soils and oilsl. Revision 0. September.

32. CCME (2002) Canadian environmental quality guidelines, National Guidelines and Standards Office. Canadian Council of Ministers of the Environment, Winnipeg, p 12

33. Föstner UG, Wittmann GTW (1981) Metal pollution in the aquatic environmental. Springer-Verlag, Berlin

34. Abessa DM, Rachid BR, Moser GA, Oliveira AJF (2012) Efeitos ambientais da disposição oceânica de esgotos por meio de emissários submarinos: uma revisão. O Mundo da Saúde 36:643661

35. Castro-Filho BM (1990) Wind driven currents in the Channel of São Sebastião: winter, 1979. Boletim do Instituto Oceanográfico 38:111-132

36. Fontes RFC (1995) As Correntes no Canal de São Sebastião. Dissertação de Mestrado. IOUSP, 159p

37. Azam F, Vaccaro RF, Gillespie PA, Moussalli EI, Hodson RE (1977) Controlled ecosystem pollution experiment: effect of mercury on enclosed water columns. Mar bacterioplank Mar Sci Comm 3:313-329

38. Malik A, Khan IF, Aleem A (2002) Plasmid incidence in bacteria from agricultural and industrial soils. World J Microbiol Biotechnol $18: 827-833$

39. Torsvik V, Sørheim R, Goksøyr J (1996) Total bacterial diversity in soil and sediment communities - a review. J Indust Microbiol 17: 170-178

40. Arslam P, Beltrame M, Tomasi A (1987) Intracelullar chromium reduction. Bioch Biphys Acta 931:10-15

41. Choudhury R, Srivastava S (2001) Zinc resistance mechanisms in bacteria. Current Sci 81:768-775

42. Duxbury T (1981) Toxicity of heavy metals to soil bacteria. FEMS Microbiol Letters 11:217-220

43. Achard-Joris M, Moreau JL, Lucas M, Baudrimont M, MesmerDudons N, Gonsalez P, Boudou A, Bordineaud JP (2007) Role of metallothioneins in superoxide radical generation during copper redox cycling: defining the fundamental function of metallothioneins. Biochemie 9:1474-1488. doi:10.1016/j. biochi.2007.06.005

44. Duxbury T, Bicknell B (1983) Metal tolerant bacterial population populations from natural and metal polluted soils. Soil Biol Bioch 15:243-250

45. Kafilzadeh F, Zahirian Y, Zolgharnein H (2013) Isolation and molecular identification of mercury resistant bacteria and detection of Escherichia coli mercuric reductase gene from wastewater of Khowr-e-Musa, Iran. Int J Biosc 3:313-318. doi:10.12692 /ijb/3.8.313-318

46. Matyar F, Kaya A, Dinçer S (2008) Antibacterial agents and heavy metal resistance in Gram-negative bacteria isolated from seawater, shrimp and sediment in Iskenderun Bay, Turkey. Sci Total Environ 407:279-285. doi:10.1016/j.scitotenv.2008.08.014
47. Malik A, Jaiswal R (2000) Metal resistance in Pseudomonas strains isolated from soil treated with industrial wastewater. World $\mathrm{J}$ Microbiol Biotechnol 16:177-182

48. Spain A, Alm C (2003) Implications of microbial heavy metal tolerance in the environment. Rev Undergrad Res 2:1-6

49. Gontang EA, Fenical W, Jensen PR (2007) Phylogenetic diversity of Gram-positive bacteria cultured from marine sediments. Appl Environ Microbiol 73:3272-3282

50. Zobeel CE (1946) Marine microbiology: a monograph on hydrobacteriology. Chronica Botanica Co, Walthman, M.A

51. Stach JEM, Bull AT (2005) Estimating and comparing the diversity of marine actinobacteria. Antonie Leeuwenhoek 87:3-9

52. Jensen PR, Mincer J, Williams PG, Fenical W (2005) Marine actinomycete diversity and natural product discovery. Antonie Leeuwenhoek 87:43-48

53. Belliveau BH, Staradub ME, Trevor JT (1991) Occurrence of antibiotic and metal resistance and plasmids in Bacillus strains isolated from marine sediment. Canad J Microbiol 37:513-520

54. Kamala-Kannan S, Mahadevan S, Krishnamoorthy R (2006) Characterization of a mercury-reduncing Bacillus cereus isolated from the Publicat Lake sediments, South East Coast of India. Archiv Microbiol 185:202-211

55. Kamala-Kannan S, Krishnamoorthy R, Lee KJ, Purosothaman A, Santhi K, Rao NR (2007) Aerobic chromate reduncing Bacillus cereus isolated from the heavy metal contaminated ennore creek sediment, North of Chennai, Tamil Nadu, South East. India Res J Microbiol 2:133-140

56. Kamala-Kannan S, Lee KJ (2008) Metal tolerance and antibiotic resistance of Bacillus species isolated from Sunchon Bay, South Korea. Biotechnol 7:149-152

57. Baker-Austin C, Wright MS, Stepaunauskas R, Mcarthur JV (2006) Co-selection of antibiotic and heavy metal resistance. Trends Microbiol 14:176-182. doi:10.3389/fmicb.2012.00399

58. SCENIHR. Scientific Committee on Emerging and Newly Identified Health Risks (2009) Assessment of the antibiotic resistance effects of biocides http://ec.europa.eu/health/ph risk/committees/04_scenihr/docs/scenihr_o_021.pdf, Accessed in: 27 de setembro de 2014

59. Hasman H, Aarestrup FM (2002) tcrB, a gene conferring transferable copper resistance in Enterococcus faecium: occurrence, transferability, and linkage to macrolide and glycopeptides resistance. Antib Agents Chemot 46:1410-1416

60. Martínez JL (2011) Bottlenecks in the transferability of antibiotic resistance from natural ecosystems to human bacterial pathogens. Front Microbio 2:265. doi:10.3389/fmicb.2011.00265

61. Velázquez-Meza ME (2005) Staphylococcus aureus methicillin-resistant: emergence and dissemination. Salud Publica Mex 47:381387

62. Anderson Borge GI, Skeie M, Sorhaug T, Langsrud T, Granum PE (2001) Growth and toxin profiles of Bacillus cereus isolated from different food sources. Int J Food Microbiol 69:237-246 